picking one or the other - both are important, and I think most psychiatrists understand that.

\section{A conclusion}

Surely we can all agree about some things: it is important not to medicalise distress that does not merit such an approach; social adversities are important risks to our mental well-being, and government policies in recent years have both exacerbated these risks and done much damage to society's ability to help those most in need as a result of them; professionals in healthcare have a responsibility to speak out both for individuals in need and also about the social conditions that contribute to their difficulties. These simple and powerful messages are obscured by wrapping them, as here, in a muddled polemic animated as much as anything else by antipsychiatry sentiment.

Allan House (D, Emeritus Professor of Liaison Psychiatry, University of Leeds, Leeds, UK. Email: a.o.house@leeds.ac.uk

\section{doi:10.1192/bjb.2021.118}

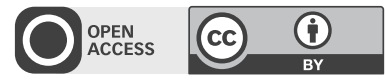

(c) The Author(s), 2022. Published by Cambridge University Press on behalf of the Royal College of Psychiatrists. This is an Open Access article, distributed under the terms of the Creative Commons Attribution licence (https://creativecommons.org/licenses/by/4.0/), which permits unrestricted re-use, distribution, and reproduction in any medium, provided the original work is properly

\section{Author's reply}

I do indeed agree with the statements in Professor House's final paragraph and with several of his other points, for example, that there are many vested interests in the debate about public mental health, and that we can see the term 'mental health' itself as both effect and cause of the individualisation of societal problems. Indeed, it is that individualisation - not, as he seems to assume, the psychiatric profession itself - that my critique is aimed at. I have always argued that all professions, including my own, need to be aware of the limitations and potential harms of their theories and practices. That is why I raised concerns not just about over prescribing, but about 'formal psychological interventions [which may be] unnecessary for most and can actually be harmful if implemented too early.'

I find Professor House's final phrase '. . . a muddled polemic animated as much as anything else by anti-psychiatry sentiment' the most worrying part of his response. This kind of language suggests that he has moved beyond rational and evidence-based argument, into ad hominem dismissal. It invites a fight rather than a debate, and since I do not identify as 'anti-psychiatry' (whatever that means) I have no desire to take up such a challenge. I will simply observe that the areas in which I take a different position from him are fundamental legitimate and increasingly common. For example, clinical psychologists' professional guidelines on formulation state that it is 'not premised on a functional psychiatric diagnosis'. ' Professor House is free to use the term differently but not to simply rule other definitions out of court. Yes, we need to offer immediate help to individuals as well as addressing adversities, but that help does not have to be based on unproven medical assumptions about the nature and origins of their distress. Yes, there are social causal factors and unclear boundaries in some physical health conditions, but no one is arguing that diabetes is a mental health problem; common sense tells us that this analogy doesn't work, despite the claims of anti-stigma campaigns and some professionals. And so on.

In 2017, a United Nations report noted 'The urgent need to... target social determinants and abandon the predominant medical model that seeks to cure individuals by targeting "disorders"' and recommended that 'Mental health policies should address the "power imbalance" rather than "chemical imbalance"'. ${ }^{2}$ Rather than allowing ourselves to be distracted by attempts to defend a failed paradigm, we all urgently need to work towards this future.

Lucy Johnstone, Consultant Clinical Psychologist and Independent Trainer. Email: LucyJohnstone16@blueyonder.co.uk

\section{Declaration of interest}

.J. is an independent trainer and offers training in formulation and the Power Threat Meaning Framework (PTMF). She has published books and articles on formulation and is one of the lead authors of the PTMF.

\section{References}

1 Division of Clinical Psychology. Good Practice Guidelines on the Use of Psychological Formulation. British Psychological Society, 2011.

2 UN General Assembly. Report of the Special Rapporteur on the Right of Everyone to the Enjoyment of the Highest Attainable Standard of Physical and Mental Health. United Nations Human Rights Council, 2017. Available from: http://www.ohchr.org/EN/Issues/Health/Pages/SRRight Healthlndex.aspx.

\section{doi:10.1192/bjb.2021.121}

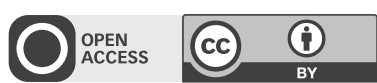

(c) The Author(s), 2022. Published by Cambridge University Press on behalf of the Royal College of Psychiatrists. This is an Open Access article, distributed under the terms of the Creative Commons Attribution licence (https://creative commons.org/licenses/by/4.0/), which permits unrestricted re-use, distribution, and reproduction in any medium, provided the original work is properly cited.

\section{Lack of respect and balance}

This editorial and current issue of BJPsych Bulletin do nothing to be 'respectful and balanced' about issues of trans health. Reprinting the article which caused the controversy in the first place means that it is exposed to a wider audience, and instead of having a counterbalancing view in another article, it has the article by Griffin et al which contains a number of anti-trans talking points. Anything which is supportive of trans people or current best practice standards for trans health is relegated to the letter pages. None of the authors of the two articles are gender identity specialists; they have instead mobilised their credentials in other areas to claim expertise in an area where they have none. The voices of trans people are either absent or denigrated as some kind of online-based groupthink.

Trans health is its own research field, and there are plenty of researchers that the Bulletin could have reached out to for a counterbalancing view. Instead, they have amplified anti-trans 
voices once more, with a sop that those with opposing views could write a letter or propose an article.

I am not seeking to silence debate, and acknowledge that this is a controversial area. However, issues around trans health are treated particularly poorly in the Bulletin. Would the Bulletin accept having two papers on women's mental health written solely by men who had no expertise in women's mental health, or two papers on ethnic minority mental health written solely by white people who had no expertise in ethnic minority mental health? If not, why is it acceptable for this to happen for trans people?

Margaret White, ST4 in Intellectual Disability Psychiatry, NHS Lothian, Edinburgh, UK. Email: m_i_white@mac.com

doi:10.1192/bjb.2021.119
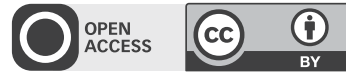

(C) The Author(s), 2022. Published by Cambridge University Press on behalf of the Royal College of Psychiatrists. This is an Open Access article, distributed under the terms of the Creative Commons Attribution licence (https://creative commons.org/licenses/by/4.0/), which permits unrestricted re-use, distribution, and reproduction in any medium, provided the original work is properly cited.

Author's reply: I thank Dr Margaret White for the letter in response to my recent editorial 'Publishing controversy'. It raised important challenges. Why have the trans health papers been published online and in print even though written by non-specialists in gender identity, and should opposing views be relegated to the Correspondence section? First, all papers published online also appear in the paper journal eventually. To do otherwise would have marked these papers out as somehow different. Dr White does not wish to silence debate, but not publishing in print form as usual would be a form of censure even if not censor. Although this is a controversial and contested area, the papers did not express extreme views. In fact, Marci Bowers, president-elect of the World Professional Association for Transgender Health, recently raised concerns similar to those expressed in the Bulletin papers. However, we remain keen to present all opinions so have commissioned papers from gender identity experts, which are making their way through the editorial process. When the papers by Griffin et al and Evans were published on First View, they quickly attracted several complaints with demands for their retraction, which as explained in the editorial was not appropriate. Those authors were invited to write opposing articles but unfortunately, for their own reasons, none took up the offer. Hence our decision to publish all the available letters alongside the original papers so readers can evaluate the arguments for themselves. I hope this and the forthcoming papers assures Dr White that no one's voice is relegated to the correspondence section in the BJPsych Bulletin, but letters, such as Dr White's, are also an invaluable element of discourse.

Norman Poole, Independent Researcher, UK. Email: norman.poole@gmail. com

doi:10.1192/bjb.2021.120

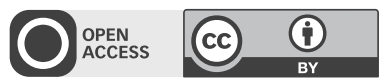

(c) The Author(s), 2022. Published by Cambridge University Press on behalf of the Royal College of Psychiatrists. This is an Open Access article, distributed under the terms of the Creative Commons Attribution licence (https://creative commons.org/licenses/by/4.0/), which permits unrestricted re-use, distribution, and reproduction in any medium, provided the original work is properly cited. 